\title{
ASSESSMENT OF GROUNDWATER QUALITY WITH SPECIAL EMPHASIS ON IRRIGATION AND DOMESTIC SUITABILITY IN SEMPATTU AND GUNDUR AREA, TIRUCHIRAPALLI DISRTICT, TAMILNADU, SOUTH INDIA
}

\author{
R. Soundar Rajan, \\ CSIR-National Geophysical Research \\ Institute, \\ Hyderabad - 500 007, India
}

\author{
R. Ramesh, Visagan Sundararajan, \\ National College, Tiruchirapalli - 620001 , \\ India
}

study area can be utilized for domestic and even drinking purposes.

Keywords: groundwater quality, irrigation and domestic suitability, USSL diagram, Sempattu area, Tiruchirapalli District, Tamil Nadu.

\section{INTRODUCTION}

Water is an important element of our environment. Without water life cannot sustain itself on Earth. It is a vital input in diverse human activities, like drinking, food, production, hydropower generation and a wide range of industries. It is to be noted that the groundwater forms a part of hydrologic cycle. It has been a more complex problem for water quality assessment. And its aim is to truly evaluate its degree of pollution for bodies of water, which will be easy to provide some principled projects and criterions for water resource's protection and their integration application. So, it has been widely applied into water quality assessment. Water is indispensable and one of the precious natural resource of our planet. Groundwater is an important natural source of water supply all over the world. It is used in irrigation, industries and domestic purpose. Groundwater quality depends on the quality of recharged water, atmospheric precipitation, in- land surface water, and on subsurface geochemical processes. Temporal changes in the origin and constitution of the recharged water, hydrologic and human factors, may cause periodic changes in groundwater quality. The population of groundwater is of major concern, firstly because of increasing utilization for human needs and secondly because of the ill effect of the increased industrial activity. The importance of water quality in human health has recently 
attracted a great deal of interest. In the developing world, $80 \%$ of all diseases are directly related to poor drinking water and unsanitary conditions (Chatterjee R, 2010). Assessment of groundwater quality is essential for particularly water from those sources which serve as drinking water sources. Groundwater quality has been deteriorating over the last few decades due to massive rise in rate of industrialization and population (Milovanovic. M, 2007).

In the first step, water samples were collected from twenty locations from tube wells in and around Sempattu and Gundur, Tiruchirappalli district. The samples were subjected to various physio-chemical analyses in Department of Agriculture (Government of Tamil Nadu), Tiruchirapalli 620020. Each of the eleven parameters: Total Dissolved solids (TDS), pH, Electrical Conductivity (EC), Carbonate $\left(\mathrm{CO}_{3}\right)$, Bicarbonate $\left(\mathrm{HCO}_{3}\right)$, Chloride $(\mathrm{CI})$, Sulfate $\left(\mathrm{SO}_{4}\right)$, Calcium (Ca), Magnesium (Mg), Sodium (Na), and Potassium (K) has been analyzed for overall quality of water for various purposes. It serves as the understanding of water quality for the possible uses by comparing the analyzed parameters of the collected water samples with BIS standards.

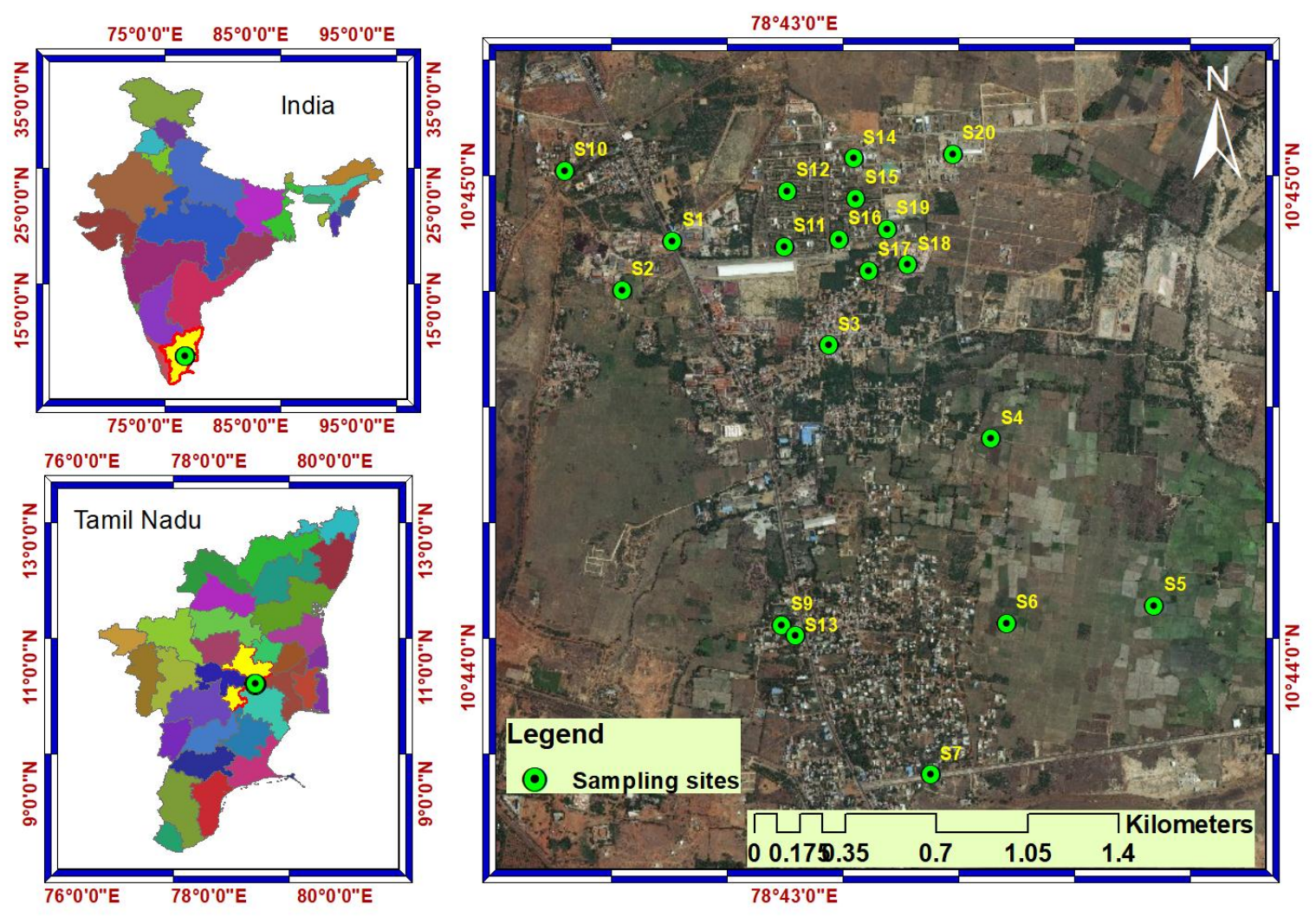

Figure 1.1. Image showing India Map, Tamil Nadu Map, Tiruchirapalli District and the sampling locations in the study area (Sempattu and Gundur area, Tiruchirapalli District)

\section{STUDY AREA:}

Tiruchirappalli is one of the most important industrial cities in Tamil Nadu. Sempattu and Gundur area are located in different parts of Tiruchirappalli city in Tamil Nadu, India. Tiruchirappalli is located at $10.8050^{\circ} \mathrm{N} 78.6856^{\circ} \mathrm{E}$. The city is at a distance of $325 \mathrm{kms}$ (202 miles) south-west of Chennai and $402 \mathrm{kms}$ north of Kanyakumari on the National Highway NH 45 and $200 \mathrm{kms}$ and $128 \mathrm{kms}$ west from the Bay of Bengal coast. The city of Madurai is situated $161 \mathrm{kms}$ south of Tiruchirappalli.
The topology of Tiruchirappalli is almost flat with a few isolated hillocks rising above the surface, the highest of which is the Rock fort. The average elevation is 289 feet. The city spread over an area of 146.7 square kilometers. Situated on the plains between the Shevaroy Hills to the North of the Palani hills to the south and south west.

The entire Tiruchchirappalli district constitutes a peneplain. The master slope of the district is towards east. The prominent geomorphic units identified in the district through interpretation of Satellite Imagery are 1) Alluvial Plains, 2) Valley Fills, 3) Buried Pediments, 4) shallow 
Pediments, 5) Pediments and 6) Structural Hills. The alluvial plains are confined to the northern bank of Cauvery River in the district. Valley fill deposits are seen mainly in the northern part adjoining the hillocks in Uppiliapuram and Thuraiyur blocks. Buried Pediments have been identified in almost all blocks in the district except Marungapuri, Manapparai, Vaiyampatti and Manikandam. Pediments, both shallow and deep, constitute the most prominent geomorphic unit in the district and are evenly distributed in the entire district. Structural hills, on the other hand, are confined to the northern and southwestern borders of the district.

The major part of the district is underlained by Archaean crystalline metamorphic complex. The important aquifer systems encountered in the district are classified into

i) Fissured, fractured and weathered crystalline formations consisting of charnockites, Granite Gneisses and ii) Unconsolidated and semiconsolidated formations. The unconsolidated and semi consolidated formations in the district include shales, sandstones and clays of Jurassic age (Upper Gondwana), marine sediment of Cretaceous age, sandstones of Tertiary age and Recent alluvial

\section{MATERIALS AND METHODS}

The water samples were collected from various tube wells in the study area. One liter of water samples were collected in polythene bottles which were cleaned with acid water, followed by rinsing twice with distilled water to avoid unpredictable changes in characteristic as per standard procedures APHA (1998) from various wells during a time between August 2018 and March 2019. Totally twenty samples were collected from twenty formations. As the Gondwana formations are well compacted and poorly jointed, the movement of groundwater in these formations is mostly restricted to shallow levels. Groundwater occurs under phreatic to semi confined conditions in the inter-granular pore spaces in sands and sandstones and the bedding planes and thin fractures in shales. In the area underlain by Cretaceous sediments, groundwater development is rather poor due to the rugged nature of the terrain and the poor quality of the formation water. Quaternary formations comprising mainly sands, clays and gravels are confined to major drainage courses in the district. The maximum thickness of alluvium is $30 \mathrm{~m}$ whereas the average thickness is about $15 \mathrm{~m}$. Groundwater in these formations is being developed by means of dug wells and filter points.

\subsection{OBJECTIVES}

The main objective of this study is assessment of quality of the groundwater used for irrigational and drinking purposes. Water in the area is generally drawn from bore wells and dug wells, though the use of submersible pumps has seen a rise over the last few years for agricultural purposes.

different locations of the study area and are subjected to various physio-chemical analyses in Department of Agriculture (Government of Tamil Nadu), Tiruchirappalli - 620020. Details of sampling locations along with their latitude and longitude are presented in Table 1.1. The standards for drinking purposes as recommended by BIS (2012) and IS-10500 (Indian Standard, 1992) have been considered for the different purposes of utility with the water quality.

TABLE 1.1: SAMPLE LOCATION FOR SEMPATTU AND GUNDUR

\begin{tabular}{|c|c|c|c|}
\hline SAMPLE NO. & LATITUDE & LONGITUDE & LOCAL IDENTITY \\
\hline 1 & $10^{\circ} 44^{\prime} 53.22^{\prime \prime} \mathrm{N}$ & $78^{\circ} 42^{\prime} 44.82^{\prime \prime} \mathrm{E}$ & Industrial Area, Sempattu, Tiruchirapalli. \\
\hline 2 & $10{ }^{\circ} 44^{\prime} 47.08^{\prime \prime N}$ & 78 \%2'38.56"E & Agriculture Area, Near Sempattu, Tiruchirapalli. \\
\hline 3 & $10{ }^{\circ} 44^{\prime} 40.25^{\prime \prime N}$ & $78^{\circ} 43^{\prime} 4.27^{\prime \prime E}$ & Anganwadi Centre, Sempattu, Tiruchirapalli. \\
\hline 4 & $10{ }^{\circ} 44^{\prime 2} 28.55^{\prime \prime N}$ & 78 \%3'24.51"E & Agricuture Area, Tiruvalarchipatti, Tiruchirapalli. \\
\hline 5 & $10{ }^{\circ} 44^{\prime} 7.78^{\prime \prime} \mathrm{N}$ & $78{ }^{\circ} 43^{\prime} 44.815^{\prime \prime} \mathrm{E}$ & Individual House, Gundur, Tiruchirapalli. \\
\hline 6 & $10^{\circ} 44^{\prime} 5.54^{\prime \prime} \mathrm{N}$ & 78 \%3'26.41"E & Individual House,Mullai Nagar, Tiruchirapalli. \\
\hline 7 & $10{ }^{\circ} 43^{\prime} 46.71 " \mathrm{~N}$ & 78 \%3'16.97"E & Individual House, Iyyanar Nagar, Tiruchirapalli. \\
\hline 8 & $10{ }^{\circ} 43^{\prime} 14.54 " \mathrm{~N}$ & $78 \stackrel{\circ}{4} 23.77 " \mathrm{E}$ & Individual House, East Street, Gundur, Tiruchirapalli. \\
\hline 9 & $10^{\circ} 44^{\prime} 5.34^{\prime \prime} \mathrm{N}$ & $78 \stackrel{\circ}{4} 2$ '58.38"E & Individual House, West Street, Gundur, Tiruchirapalli. \\
\hline 10 & $10{ }^{\circ} 45^{\prime} 01.96 " \mathrm{~N}$ & $78 \stackrel{\circ}{4} 31.35 " \mathrm{E}$ & Individual House, Pasumai Nagar, Near Morais City, Tiruchirapalli. \\
\hline 11 & $10{ }^{\circ} 44^{\prime} 52.51 " \mathrm{~N}$ & $78 \stackrel{\circ}{4} 2$ '58.68"E & 1 st Cross, Morais City,Tiruchirapalli. \\
\hline 12 & $10{ }^{\circ} 44^{\prime} 59.43 " \mathrm{~N}$ & $78 \stackrel{\circ}{4} 259.11 " \mathrm{E}$ & 3 rd cross, Morais City,Tiruchirapalli. \\
\hline 13 & $10{ }^{\circ} 44^{\prime} 3.99^{\prime \prime} \mathrm{N}$ & $78{ }^{\circ} 43^{\prime} 0.13^{\prime \prime} \mathrm{E}$ & 5 th Sector,Morais City,Tiruchirapalli. \\
\hline 14 & $10^{\circ} 45^{\prime} 3.52^{\prime \prime} \mathrm{N}$ & $78 \stackrel{\circ}{\circ} 3^{\prime} 7.33^{\prime \prime} \mathrm{E}$ & 6 th Sector, Morais City, Tiruchirapalli. \\
\hline
\end{tabular}




\begin{tabular}{|l|l|l|l|}
\hline 15 & $10^{\circ} 44^{\prime} 58.51^{\prime \prime} \mathrm{N}$ & $78^{\circ} 43^{\prime} 7.57^{\prime \prime} \mathrm{E}$ & Residency, Morais City,Tiruchirapalli. \\
\hline 16 & $10^{\circ} 44^{\prime} 53.42^{\prime \prime} \mathrm{N}$ & $78^{\circ} 43^{\prime} 5.49^{\prime \prime} \mathrm{E}$ & Green house apartment,Morais City, Tiruchirapalli. \\
\hline 17 & $10^{\circ} 44^{\prime} 49.49^{\prime \prime} \mathrm{N}$ & $78^{\circ} 4^{\prime} 9.19^{\prime \prime} \mathrm{E}$ & South 1st Cross, Morais City, Tiruchirapalli. \\
\hline 18 & $10^{\circ} 44^{\prime} 50.24^{\prime \prime} \mathrm{N}$ & $78^{\circ} 43^{\prime} 14.13^{\prime \prime} \mathrm{E}$ & 8 th Sector, Morais City, Tiruchirapalli. \\
\hline 19 & $10^{\circ} 44^{\prime} 54.68^{\prime \prime} \mathrm{N}$ & $78^{\circ} 43^{\prime} 11.57^{\prime \prime} \mathrm{E}$ & Coconunt Garden. Morais City, Tiruchirapalli. \\
\hline 20 & $10^{\circ} 45^{\prime} 4.03^{\prime \prime} \mathrm{N}$ & $78^{\circ} 43^{\prime} 19.69^{\prime \prime} \mathrm{E}$ & Gloden Wood House, Morais City, Tiruchirapalli. \\
\hline
\end{tabular}

Water samples in all representing the area of investigation were collected from selected points in and around Sempattu and Gundur, Tiruchirappalli district in polythene containers. As many as fifty constituents can be determined in a water analysis. But usually all are not determined.
Only such constituents, the determination of which is essential and useful for the particular study in view are carried out. It is also to be noted that a complete water analysis for all constituents is very expensive.

\section{RESULTS AND DISCUSSIONS}

\subsection{HYDRO-GEOCHEMICAL INTERPRETATION}

Water samples have been collected from 20 tube wells and analyzed. The results are tabulated in ppm are depicted in Table 4.1. and the graphical representation of the same is also given as Figure 4.1.

\begin{tabular}{|c|c|c|c|c|c|c|c|c|c|c|c|}
\hline $\begin{array}{c}\text { Sample } \\
\text { No. }\end{array}$ & $\mathbf{p}^{\mathbf{H}}$ & EC & $\begin{array}{c}\text { TDS } \\
(\mathrm{mg} / \mathrm{L})\end{array}$ & $\begin{array}{c}\mathrm{CO}_{3} \\
(\mathrm{mg} / \mathrm{L})\end{array}$ & $\begin{array}{c}\mathrm{HCO}_{3} \\
(\mathrm{mg} / \mathrm{L})\end{array}$ & $\begin{array}{c}\mathrm{SO}_{4} \\
(\mathrm{mg} / \mathrm{L})\end{array}$ & $\begin{array}{c}\mathrm{Cl} \\
(\mathrm{mg} / \mathrm{L})\end{array}$ & $\begin{array}{c}\mathrm{Ca}^{2+} \\
(\mathrm{mg} / \mathrm{L})\end{array}$ & $\begin{array}{c}\mathrm{Mg}^{2+} \\
(\mathrm{mg} / \mathrm{L})\end{array}$ & $\begin{array}{c}\mathrm{Na}^{2+} \\
(\mathrm{mg} / \mathrm{L})\end{array}$ & $\begin{array}{c}\mathbf{K}^{2+} \\
(\mathrm{mg} / \mathrm{L})\end{array}$ \\
\hline 1 & 7.17 & 4.17 & 2670 & NIL & 235 & 162 & 1163 & 452 & 259 & 1126 & 0.32 \\
\hline 2 & 7.09 & 3.98 & 2550 & NIL & 243 & 153 & 1269 & 386 & 241 & 1123 & 0.23 \\
\hline 3 & 7.75 & 1.45 & 928 & NIL & 116 & 83 & 246 & 258 & 146 & 216 & 0.32 \\
\hline 4 & 7.26 & 4.03 & 2580 & NIL & 369 & 112 & 1548 & 478 & 249 & 1124 & 0.36 \\
\hline 5 & 6.52 & 0.24 & 154 & NIL & 29 & 12 & 96 & 62 & 43 & 28 & 0.25 \\
\hline 6 & 7.08 & 1.05 & 675 & NIL & 129 & 36 & 189 & 124 & 89 & 189 & 0.34 \\
\hline 7 & 7.39 & 0.77 & 493 & NIL & 118 & 54 & 124 & 152 & 114 & 172 & 0.25 \\
\hline 8 & 6.99 & 1.88 & 1203 & NIL & 249 & 92 & 684 & 452 & 246 & 589 & 0.23 \\
\hline 9 & 7.24 & 0.96 & 614 & NIL & 116 & 124 & 289 & 206 & 116 & 259 & 0.21 \\
\hline 10 & 6.99 & 7.14 & 4570 & NIL & 658 & 245 & 2635 & 458 & 259 & 1258 & 0.33 \\
\hline 11 & 7.84 & 0.92 & 584 & NIL & 119 & 104 & 254 & 129 & 79 & 326 & 0.24 \\
\hline 12 & 7.40 & 1.60 & 1024 & NIL & 248 & 125 & 785 & 189 & 142 & 569 & 0.37 \\
\hline 13 & 7.36 & 1.83 & 1168 & NIL & 236 & 132 & 825 & 258 & 196 & 746 & 0.23 \\
\hline 14 & 7.76 & 1.07 & 685 & NIL & 158 & 147 & 369 & 189 & 125 & 368 & 0.21 \\
\hline 15 & 7.32 & 2.01 & 1286 & NIL & 282 & 135 & 989 & 348 & 216 & 857 & 0.25 \\
\hline 16 & 6.51 & 11.19 & 7630 & NIL & 369 & 321 & 5478 & 354 & 248 & 6581 & 0.36 \\
\hline 17 & 6.92 & 10.1 & 6460 & NIL & 458 & 258 & 5356 & 365 & 285 & 5789 & 0.23 \\
\hline 18 & 7.25 & 1.16 & 742 & NIL & 156 & 114 & 359 & 289 & 126 & 485 & 0.21 \\
\hline 19 & 7.20 & 1.19 & 760 & NIL & 182 & 127 & 369 & 275 & 138 & 578 & 0.25 \\
\hline 20 & 7.10 & 0.99 & 637 & NIL & 121 & 94 & 232 & 242 & 126 & 116 & 0.36 \\
\hline
\end{tabular}

$\mathrm{mg} / \mathrm{L}=$ milligrams per liter, $\mathrm{ppm}=$ parts per million, $\mathrm{dS} / \mathrm{m}=$ deci Siemens per meter

TABLE 4.1. CONCENTRATION OF CHEMICAL PARAMETERS 
International Journal of Engineering Applied Sciences and Technology, 2019

Vol. 4, Issue 4, ISSN No. 2455-2143, Pages 147-154

Published Online August 2019 in IJEAST (http://www.ijeast.com)

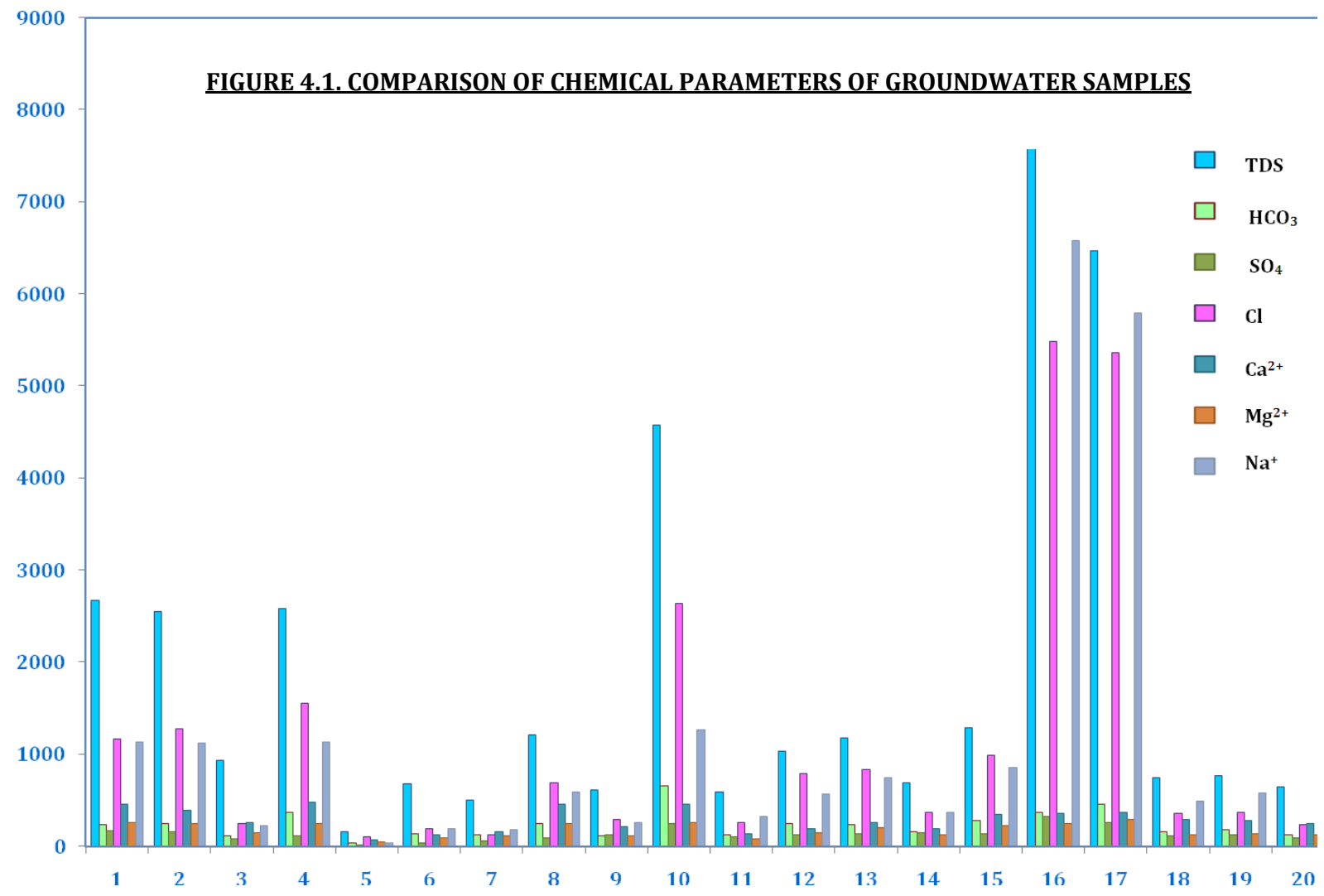

A typical classification of hydrogeochemical facies for groundwater is shown in Figure 4.2., which clearly explains the variations of cation and anion concentration in the study area. The diamond shaped field of piper diagram is further divided into further six classes, namely $\mathrm{Ca}-\mathrm{HCO}_{3}, \mathrm{Na}-\mathrm{Cl}$, mixed $\mathrm{Ca}-\mathrm{Na}-\mathrm{HCO}_{3}$, mixed $\mathrm{Ca}-\mathrm{Mg}$ $\mathrm{Cl}, \mathrm{Ca}-\mathrm{Cl}$ and $\mathrm{Na}-\mathrm{HCO}_{3}$. In the study area $40 \%$ of the samples belong to the mixed Ca-MG-Cl type and followed by $\mathrm{Na}-\mathrm{Cl}$ type (35\%), $\mathrm{Ca}-\mathrm{Cl}$ type (25\%).

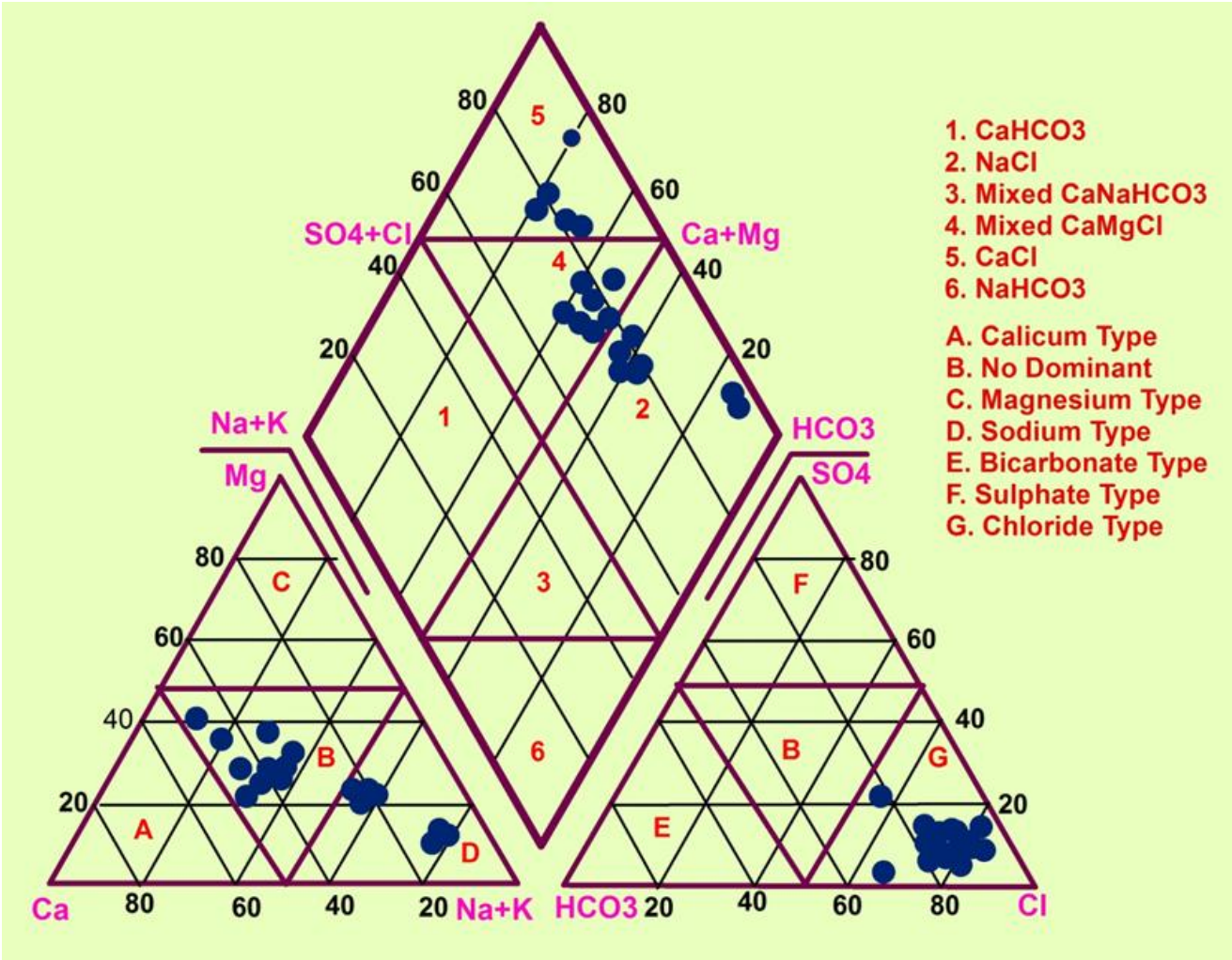




\subsection{USSL PLOT}

The U.S. Regional Salinity Laboratory has constructed a diagram for the classification of irrigation waters (Wilcox 1955) describing sixteen classes with reference to Sodium Adsorption Ratio (SAR) as an index for sodium hazard and electrical conductivity (EC) as an index for salinity hazard (Figure 4.3.).

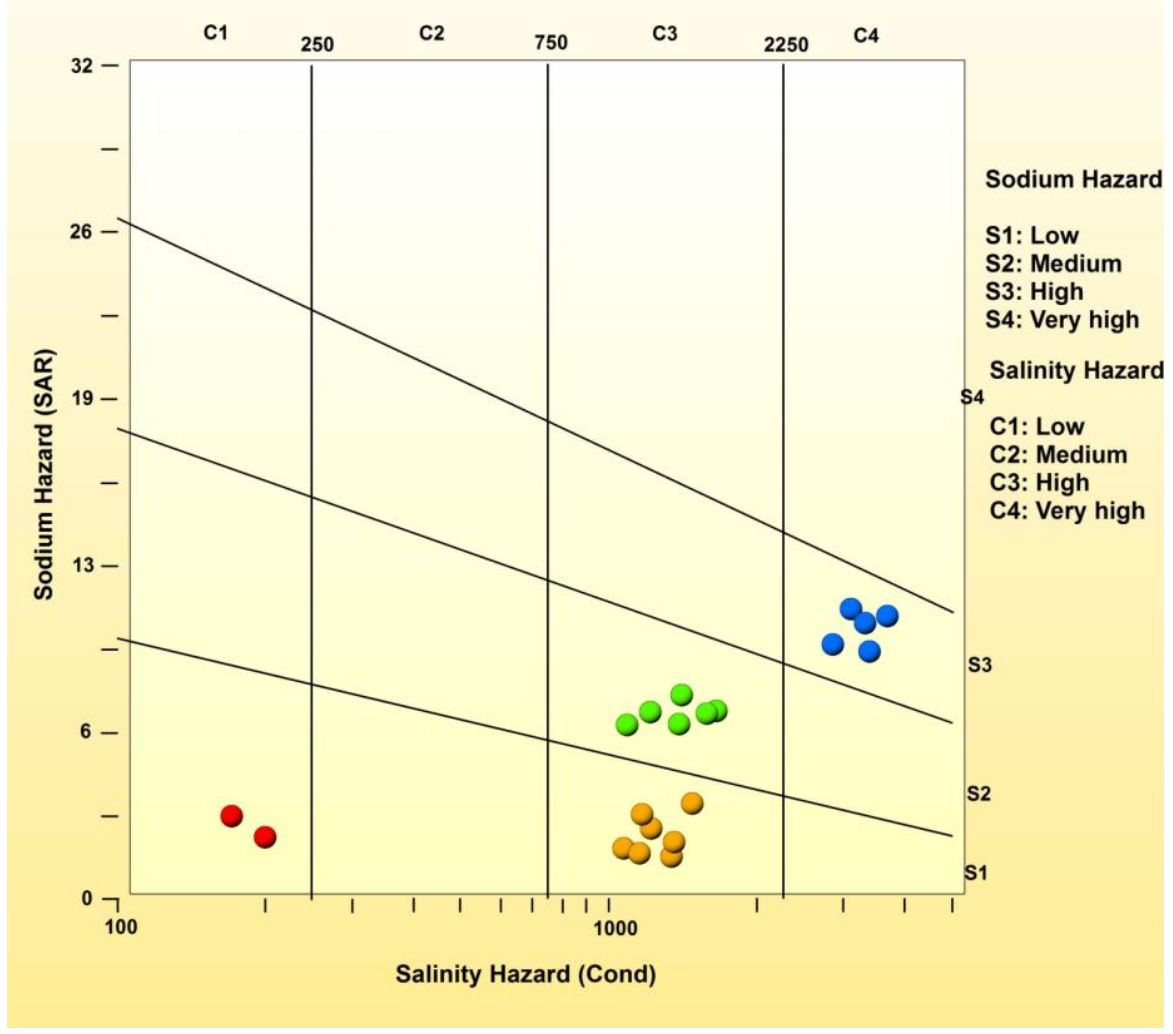

The USSL diagram (USSL 1954) highlights that seven samples fall under the field of C3S1, which indicates water having high salinity and low sodium alkali hazard Whereas, 6 samples fall under C3S2 category indicating high salinity hazard and medium sodium hazard and 5 samples are having very high salinity and high alkali hazard (C4S3), while remaining two samples fall under the C1S1 field. Medium-salinity water (C2) can be used if a moderate amount of leaching occurs. Plants with moderate salt tolerance can be grown in most instances without special practices of salinity control. High salinity water (C3) with low sodium water (S1) is satisfactory for plants having moderate salt tolerance, on soils of moderate permeability with leaching. Very high salinity water (C4) and high sodium water (S3) cannot be used for irrigation purpose under ordinary conditions but may be used occasionally, under unavoidable circumstances.

\section{CONCLUSION}

Water samples were collected from 20 tube wells in and around Sempattu and Gundur, Tiruchirappalli district for hydrogeochemical studies. Water samples have been analyzed for cation and anion in ppm at Department of Agriculture (Government of Tamilnadu), Tiruchirappalli - 620020 .

The following conclusions are drawn from this study.

1) Based on TDS range, samples numbers $1,4,8$, $9,10,13,15,16,17,19$ from the study area are found to be Fresh water; sample numbers 2, 3, $5,11,12,14,18$ from the study area are found to be Slightly saline and sample numbers 6, 7, 20 from the study area are found to be Moderately saline.

2) The electrical conductivity and the $\mathrm{pH}$ values from the locations $1,2,3,4,6,7,9,11,12,13$, $14,15,18,19$ and 20 are found to be alkaline.

3) The sodium absorption ratio varies between 3.86 and 379.32 .

4) The ratio of $\mathrm{CI}$ to $\left[\mathrm{CO}_{3}+\mathrm{HCO}_{3}\right]$, is ranging between 1.05 and 14.85 . 


\section{International Journal of Engineering Applied Sciences and Technology, 2019 Vol. 4, Issue 4, ISSN No. 2455-2143, Pages 147-154 \\ Published Online August 2019 in IJEAST (http://www.ijeast.com)}

5) Carbonate value is nil for all the samples, and, as the groundwater has no concentrations of sea water, however, experiencing chloride contamination and found that the water is not affected by the use of fertilizers.

6) The calcium values range between 62 and 478 . The sample numbers 5, 6, 7, 11, 12 and 14 are found to be within the permissible limits of WHO as well as BIS.

7) According to WHO and BIS, the magnesium values of sample numbers 5, 6 and 11 are found to be within the permissible limits.

8) The sodium values of sample numbers 5 and 20 are found to be within the permissible limits of WHO as well as BIS.

9) Potassium is within the permissible limits of WHO and BIS in all the locations.

10) Except for samples 11 and 18, the bicarbonates are within the permissible limits.

11) The USSL diagram (USSL 1954) reveals that 7 samples fall under the field of C3S1, which indicates water having high salinity and low sodium alkali hazard Whereas, 6 samples fall under $\mathrm{C} 3 \mathrm{~S} 2$ category indicating high salinity hazard and medium sodium hazard and 5 samples are having very high salinity and high alkali hazard (C4S3), while remaining two samples fall under the C1S1 field. Mediumsalinity water $(\mathrm{C} 2)$ can be used if a moderate amount of leaching occurs. Plants with moderate salt tolerance can be grown in most instances without special practices of salinity control. High salinity water (C3) with low sodium water (S1) is satisfactory for plants having moderate salt tolerance, on soils of moderate permeability with leaching. Very high salinity water (C4) and high sodium water (S3) cannot be used for irrigation purpose under ordinary conditions but may be used occasionally, under unavoidable circumstances.

An attempt has been made to understand the hydrogeochemical characters in and around Sempattu and Gundur area at Tirchirappalli. It can be concluded the groundwater quality in the study area may be suitable for agricultural purposes. If treated properly the groundwater in the study area can be utilized for domestic and even drinking purposes.

\section{REFERENCES}

1. Belkhiri L, Boudoukha A, Mouni L, Baouz T (2010) Multivariate statistical characterization of groundwater quality in Ain Azel plain, Algeria. African Journal of Environmental Science and Technology. 4(8): 526-534.

2. Chandrasekar N, Selvakumar S, Srinivas Y, John Wilson JS, Simon Peter T, Magesh NS (2013)
Hydrogeochemical assessment of groundwater quality along the coastal aquifers of southern Tamil Nadu, India. Environ Earth Sci 71: 4739-4750.

3. Chidambaram S, Senthil Kumar G, Prasanna MV, Peter AJ, Ramanthan AL, Srinivasamoorthy K (2009) A study on the hydrogeology and hydrogeochemistry of groundwater from different depths in a coastal aquifer: Annamalai Nagar, Tamilnadu, India. Environmental geology. 57 (1) pp. 59-73.

4. Elangbam JK Singh, Gupta A, Singh NR (2013) Groundwater quality in Imphal west District,Manipur, India, with multivariate statistical analysis of data. Environ Sci Pollut Res 20: 24212434.

5. Elango L, Kannan R, Senthilkumar (2003) Major ion chemistry \& identification of hydro geochemical processes of groundwater in a part of Kancheepuram District, Tamil Nadu, India. Journal of environmental Geosciences, 10 (4). pp 157-166. 6. Gajendran, C, and Thamarai, P (2008) Relation between surface water qualities assessment in Nambiyar River basin, Tamil Nadu, India: A statistical Approac, International Journal of Future on Future Engineering and Technology, Vol. 4, No.2, pp. 27-33.

7. Gibbs RJ (1970) Mechanisms controlling world water chemistry. Science 17:1088-1090.

8. Giridharan L, Venugopal T, Jayaprakash M (2008) Evaluation of the seasonal variation on the geochemical parameters and quality assessment of the groundwater in the proximity of River Cooum, Chennai, India. Environ Monit Assess 143: 161178.

9. Hazar B, Rachida B, Elango L, Fairouz S, Naceur O (2015) Characterization of mechanisms and processes of groundwater salinization in irrigated coastal area using statistics, GIS and hydrogeochemical investigations. Environ Sci Pollut Res 22: 2643-2660.

10. Jones BF, Vengosh A, Rosenthal E, Yechieli Y (1999) Geochemical investigation of groundwater quality, In: seawater intrusion in a coastal aquifersconcepts, methods and practices, Kluwer, Netherlands, pp 51-71.

11. Kazi T, Arain M, Jamali M, Jalbani N, Afridi H, Sarfraz R, Baig J, Shah A (2009) Assessment of water quality of polluted lake using multivariate statistical techniques: A case study. Ecotoxicology and Environmental Safety 72: 301- 309.

12. Krishna Kumar S, Chandrasekar N, Seralathan P, Prince S. Godson, Magesh NS (2011) Hydrogeochemical study of shallow carbonate aquifers, Rameswaram Island, India. Environ Monit Assess 184: 4127-4138.

13. Purushothaman P, Someshwar Rao M, Rawat YS, Kumar CP, Gopal Krishan, Parveen T (2013) Evaluation of hydrogeochemistry and water quality 
in Bist-Doab region, Punjab, India. Environ Earth Sci DOI 10.1007/s12665-013-2992-9.

14. Selvam S, Manimaran G, Sivasubramanian P (2013) Hydrochemical characteristics and GISbased assessment of groundwater quality in the coastal aquifers of Tuticorin corporation, Tamilnadu, India. Appl Water Sci (2013) 3:145159.

15. Selvakumar S, Ramkumar K, Chandrasekar N, Magesh NS, Kaliraj S (2015) Groundwater quality and its suitability for drinking and irrigational use in the southern Tiruchirappalli district, Tamil Nadu, India. Appl Water Sci DOI 10.1007/s 13201-0140256-9.

16. Sivasubramanian P, Balasubramanian. N, John Prince Soundranayagam, Chandrasekar N (2013) Hydrochemical characteristics of coastal aquifers of Kadaladi, Ramanathapuram District, Tamilnadu, India. Appl Water Sci (2013) 3:603-612.

17. Singh K, Malik A, Sinha S (2005) Water quality assessment and apportionment of pollution sources of Gomti river (India) using multivariate statistical techniques-a case study. Analytica Chimica Acta 538: 355-374.

18. Sridhar S.G.D, Kanagaraj G, Mahalingam S, Amaladas P (2013) Hydrochemical analysis of Groundwater between Sadras and Chinnakuppam, Kancheepuram District, Tamil Nadu, India. Journal of Academia and Industrial Research 2 (3), 160166.

19. Srinivas Y, Hudson Oliver D, Stanley Raj A, Chandrasekar N (2014) Quality assessment and hydrogeochemical characteristics of groundwater in Agastheeswaram taluk, Kanyakumari district, Tamil Nadu, India. Chin. J. Geochem. (2014) 33:221-235.

21. Srinivasamoorthy K, Gopinath M, Chidambaram S, Vasanthavigar M, Sarma V.S (2014) Hydrochemical characterization and quality appraisal of groundwater from Pungar sub-basin, Tamilnadu, India. Journal of King Saud UniversityScience, 37 (1): 51-52.

22. Chatterjee R, Goorab T, Paul S (2010) Groundwater quality assessment of Dhanbad district, Jharkhand, India. Bull Eng Geol Environ 69: 137-141.

23. Milovanovic M (2007). Water quality assessment and determination of pollution sources along the Axios / Vardar River, Southeast Europe. Desalination 213: 159-173.

24. Vasanthavigar M, Srinivasamoorthy K, Gandhi R, Chidambaram S, Vasudevan S (2010) Application of water quality index for groundwater quality assessment: Thirumanimuttur sub-basin Tamilnadu, India. Env. Monit. Assess. 171 (1-4): 595-609.

25. S. K.Nag, and Shreya Das, (2014) Quality Assessment of Groundwater with Special Emphasis on Irrigation \& Domestic Suitability in Suri I \& II
Blocks, Birbhum Dt, West Bengal, India. American Journal of Water Resources, vol. 2, no. 4. 